\title{
Merging the concepts of pseudokarst and paleoseismicity in Sweden: A unified theory on the formation of fractures, fracture caves, and angular block heaps
}

\author{
Nils-Axel Mörner ${ }^{1}$ and Rabbe Sjöberg ${ }^{2}$ \\ ${ }^{1}$ Paleogeofysics \& Geodynamics, Stockholm, Sweden \\ ${ }^{2}$ Obbola, Umeå, Sweden
}

\begin{abstract}
Sweden has thousands of caves cut into the bedrock, two thirds of which occur in the crystalline bedrock, and hence represent pseudokarst phenomena. The formation of these caves can only be understood in terms of paleoseismics. In this paper, we review the parallel evolution of the concept of pseudokarst caves and of the concept of paleoseismic activity in Sweden, and combine both concepts into a unified theory on the formation of fractures, fracture caves and angular block heaps.
\end{abstract}

Keywords: $\quad$ pseudokarst, fracture caves, block caves, paleoseismics, methane venting tectonics

Received 21 August 2018; Revised 5 October 2017; Accepted 7 October 2018

Citation: Mörner N.-A. and Sjöberg R., 2018. Merging the concepts of pseudokarst and paleoseismicity in Sweden: A a unified theory on the formation of fractures, fracture caves, and angular block heaps. International Journal of Speleology, 47 (3), 393-405. Tampa, FL (USA) ISSN 0392-6672 https://doi.org/10.5038/1827-806X.47.3.2225

\section{INTRODUCTION}

The Swedish Speleological Society has a database including 2871 classified caves (SSF, 2018). Out of those, 410 (14.3\%) refer to true karst caves, 309 $(10.8 \%)$ refer to shore caves (including "tunnel caves"), and the vast majority of sites (1919 or 66.8\%) refer to block and fracture caves. This is an effect of the fact that Swedish bedrock predominantly consists of crystalline bedrock, especially gneisses and granites. The word "pseudokarst" has a somewhat unclear definition. It implies, however, that it is not a question of dissolutional weathering, but coastal erosion (shore caves), bedrock fracturing (the cave formation of which has been termed quite differently; viz.: granite caves, bedrock caves, boulder caves, block caves, block heaps, etc) and scree deposits.

In this paper we review the evolution of observing, documenting and understanding such pseudokarst caves and scree accumulations in Sweden. Previous standard references were by Sjöberg (1994a, b), Mörner (2003) and Mörner \& Sjöberg (2011).

The Swedish speleological society (Sveriges SpeleologFörbund, SSF) was formed in 1966 by Leander Tell. It issues a journal named "Grottan" (The Cave), has a publication series named "Svenska Grottor" (Swedish Caves) and a database "Grottdatabasen" (SSF, 2018). In 2007, SSF hosted the Baltic Speleological Congress on the Island of Gotland (Gustafsson, 2007), and in
2011, it hosted the Second International Conference on Granite Caves (Mörner \& Sjöberg, 2011).

Figure 1 shows the distribution of caves registered in the SSF database (SSF, 2018). Table 1 gives the distribution of numbers and lengths of pseudokarst caves in Sweden: the majority are less than $25 \mathrm{~m}$ long and the longest 2,633 $\mathrm{m}$ long. The lengths of the 10 longest pseudokarst caves are given in Table 2 .

Fracture caves and block caves are formed by tectonic processes and typically consist of fracture patterns and angular blocks with sharp edges, as illustrated in Fig. 2. Tunnel caves (Sjöberg, 1986a, 1990) are formed by littoral erosion as illustrated in Fig. 3.

Leander Tell is regarded as the "Father of Swedish Speleology" with a benchmark book (Tell, 1955), followed by other books (Tell, 1962, 1969) and a number of cave catalogues (Tell, 1963, 1966, 1970, 1974).

Caves have, of course, been observed far back in history. In the early $17^{\text {th }}$ century, King Karl XI was carried up to a shore cave hanging in the mountainside at $120 \mathrm{~m}$ a.s.1. in Ångermanland (Fig. 4), where the rate of uplift has been at its maximum. During his travel to Lapland, Carl von Linné visited this cave and several other caves along the Bothnian coast (Linnaeus, 1732). Caves were often hiding places for robbers and malicious people. In pre-historic times, however, they seem to have been avoided for mythological reasons, rather than used for habitation 
or other cultural activities. Only occasionally do we find ancient tools in Swedish caves.

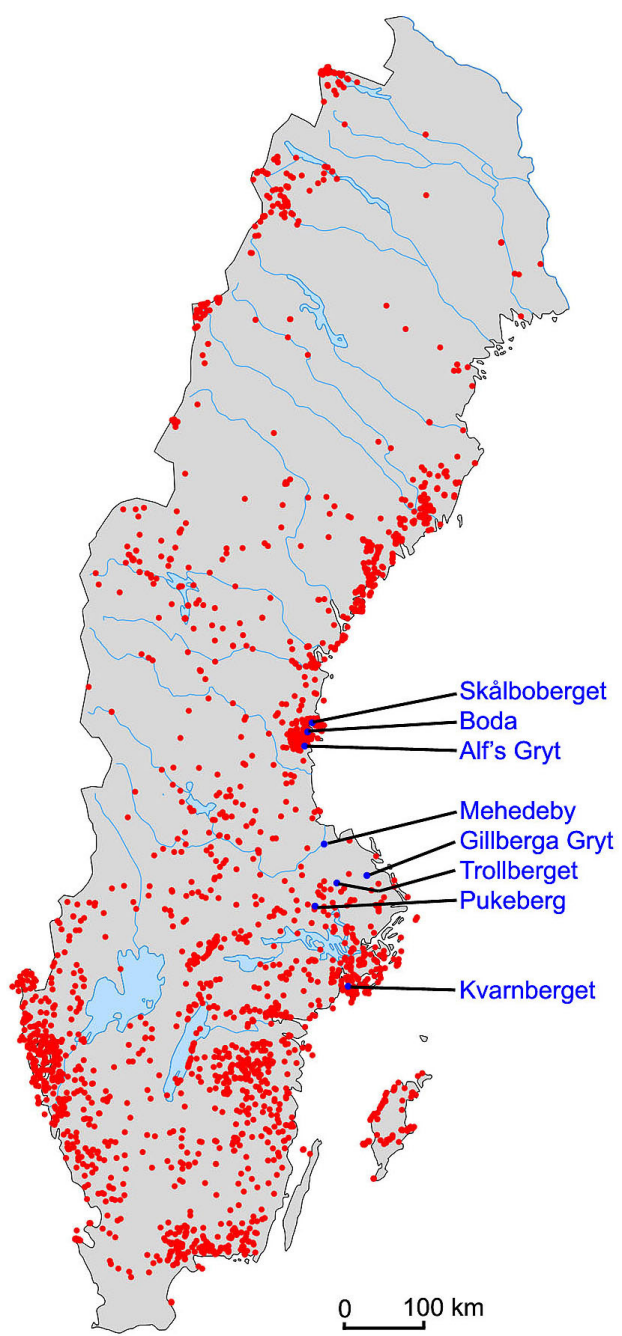

Fig. 1. Distribution of 2871 caves (red dots) registered in the Swedish cave database (SSF, 2018). The caves named refer to the six caves in the "gallery" examples plus two MVT sites discussed in the text.

Table 1. Distribution of pseudokarst caves (in total 2054) with respect to their length.

\begin{tabular}{|c|c|}
\hline Length in $\mathbf{~ m}$ & Number \\
\hline$>2500$ & 1 \\
\hline $1000-2500$ & 1 \\
\hline $500-1000$ & 4 \\
\hline $250-500$ & 4 \\
\hline $100-250$ & 25 \\
\hline $50-100$ & 38 \\
\hline $25-50$ & 144 \\
\hline $10-25$ & 463 \\
\hline$<10$ & 1323 \\
\hline
\end{tabular}

\section{FRACTURE CAVES AND BLOCK CAVES}

There are numerous caves in the Precambrian crystalline bedrock of Sweden associated with fractures and block tectonics. There are also heaps of huge blocks, within which there are caves. These structures have nothing to do with weathering and dissolution, but refer to broken up fragments from the bedrock surface. They are all examples of "pseudokarst", although they usually have been termed "fracture caves", "block caves", "boulder
Table 2. List of the 10 longest pseudokarst caves in Sweden.

\begin{tabular}{|l|c|c|c|}
\hline \multicolumn{1}{|c|}{ Name of cave } & County & $\begin{array}{c}\text { Length } \\
\text { (m) }\end{array}$ & $\begin{array}{c}\text { Type of } \\
\text { cave }\end{array}$ \\
\hline Bodagrottorna & Hälsingland & 2,633 & $\begin{array}{c}\text { fracture } \\
\text { cave }\end{array}$ \\
\hline Hölickgrottan & Hälsingland & 1,340 & $\begin{array}{c}\text { fracture } \\
\text { cave }\end{array}$ \\
\hline Almekärrgrytet & Småland & 610 & $\begin{array}{c}\text { fracture } \\
\text { cave }\end{array}$ \\
\hline Örnnäset & Hälsingland & 520 & talus cave \\
\hline Strångbergsgrottan & Jämtland & 510 & $\begin{array}{c}\text { fracture/ } \\
\text { block cave }\end{array}$ \\
\hline Gillberga gryt & Uppland & 500 & $\begin{array}{c}\text { fracture/ } \\
\text { block cave }\end{array}$ \\
\hline Ö. Klövbergsgrottan & Södermanland & 362 & block cave \\
\hline Frugrottan & Södermanland & 320 & $\begin{array}{c}\text { fracture/ } \\
\text { block cave }\end{array}$ \\
\hline Töllsjögrottan & Västergötland & 300 & talus cave \\
\hline $\begin{array}{l}\text { Stora } \\
\text { Trångbergsgrottan }\end{array}$ & Västmanland & 250 & talus cave \\
\hline
\end{tabular}

caves", "granite caves" and "talus caves" (it should be noted that the word "boulder" has been used in Sweden for big blocks without respect to presence or absence of rounding).

Because Swedish geological mapping is divided into a solid rock branch and a Quaternary branch, caves and loose block heaps happened to fall in between those units, and therefore were largely ignored in the geological mapping. Instead, the study of Swedish block caves came to be driven by the spirit and curiosity of individual persons like Bergsten (1943), Agrell (1981, 1982), Isacsson (1982, 1990), Sjöberg (1987a, 1994a), and Mörner (2003).

\section{Deformational till and bouldery moraines}

In a very few cases boulder heaps can be explained as "deformation till" in the sense of Dreimanis (1969) and Mörner (1973). This concept has been generally ignored in Swedish Quaternary geology, however.

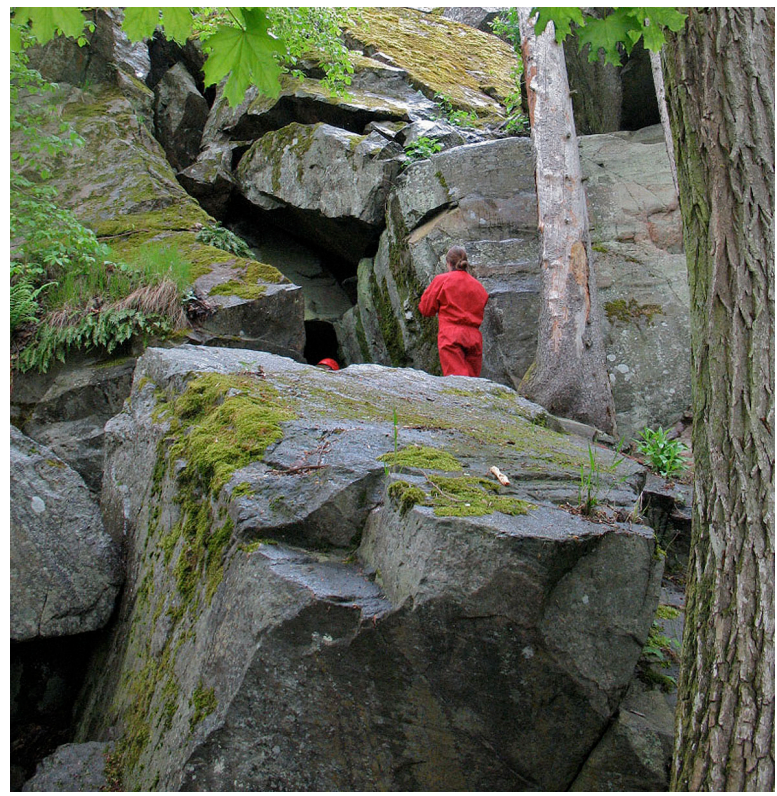

Fig. 2. A typical seismotectonic cave consisting of huge angular blocks torn out of the bedrock due to a major paleoseismic event in postglacial time. Only a seismic event is capable to move these huge blocks anti-gravitationally upwards (which is the case here, as it is in many other cave sites). 
Some De Geer moraines (terminal end moraines) consist of big boulders and have become known as "bouldery moraines". The majority of "pseudokarst caves" in Sweden have nothing to do with icemarginal till accumulations, however. Neither have they anything to do with "glacial tectonics".

In a few cases, however, bouldary moraines of a proposed seismic origin have been described by De Geer (1938, 1940) and Mörner (1990), suggesting that the bedrock surface was broken up into loose blocks by earthquakes when still in subglacial position (Mörner, 1978, 2017b, c).

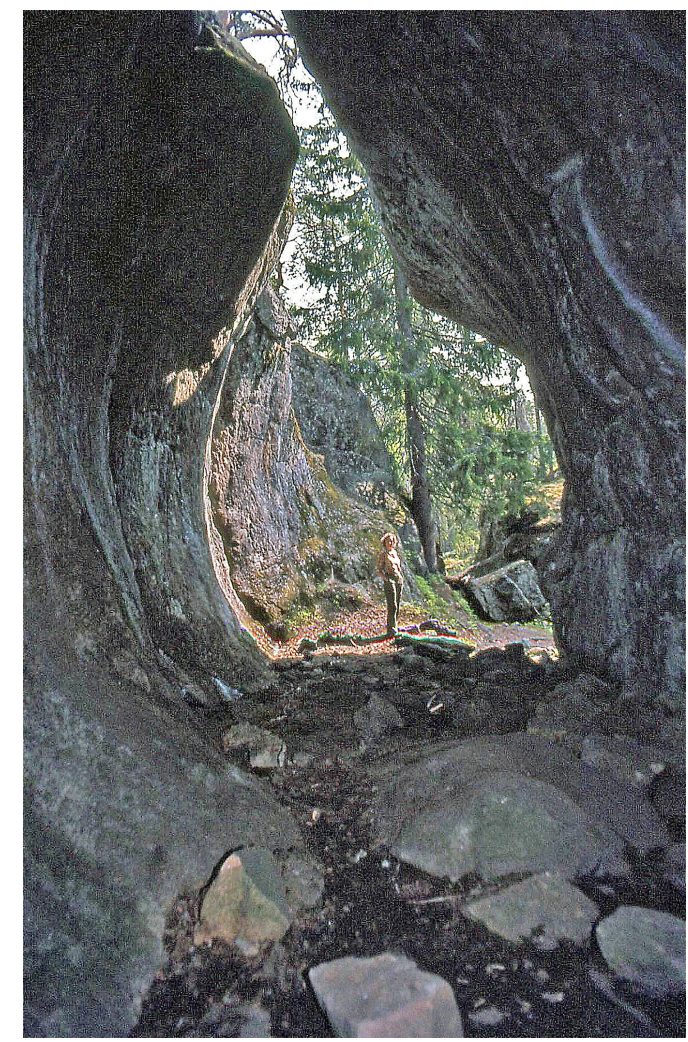

Fig. 3. The Räckebergskyrkan tunnel cave located at an elevation of $180 \mathrm{~m}$ a.s.I. It is the largest and highest elevated tunnel cave in Sweden. It can be regarded as an example of a tunnel cave.

\section{Bedrock fracturing, seismotectonics and paleoseismology}

Open bedrock fractures, granite caves, boulder caves, block caves and block heaps imply fracturing of the former surface of the crystalline bedrock. In association with glaciation and deglaciation, the Scandinavian bedrock became smoothly polished and striated (Mörner et al., 2008, Fig. 9). Therefore, fractures and faults in this glaciated bedrock surface provide evidence of postglacial fracturing. This fracturing of previously solid bedrock must be understood in terms of seismotectonics (Mörner, 1978, 2003; Sjöberg, 1987a, 1994a). Today, Sweden is a country of low to moderately-low seismic activity. At the time of deglaciation, however, Sweden has, in the last decades, turned out to be an area of highseismicity (Mörner, 1991, 2003). Therefore, there is no longer any geodynamic problem in referring Swedish "pseudokarst" phenomena to seismotectonics (Mörner \& Sjöberg, 2011). This applies not only to the deglacial phase (e.g., Mörner, 1991, 2003) but also to the Late Holocene (Mörner, 2007, 2009, 2017b).

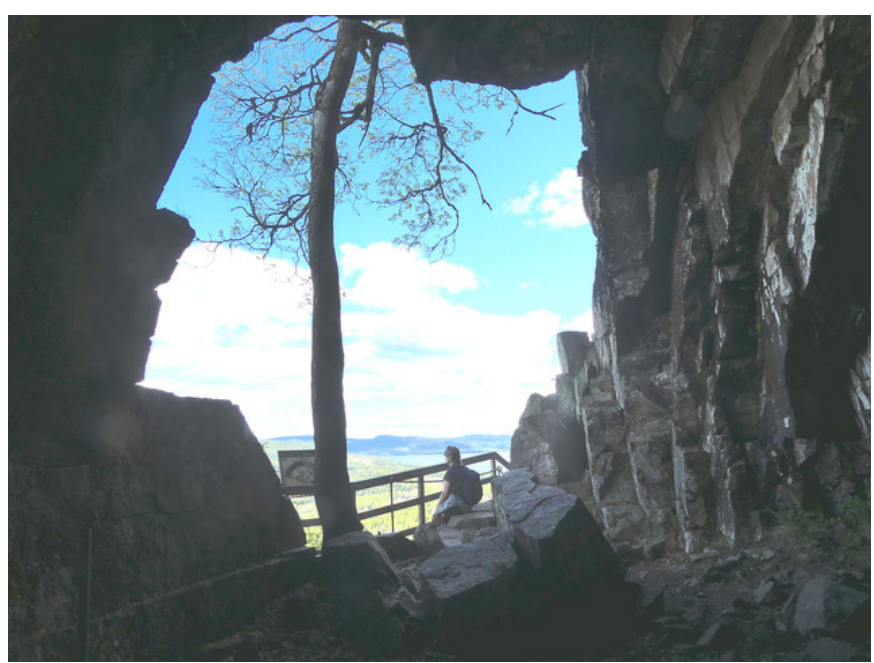

Fig. 4. A shore cave ("Kungsgrottan") is hanging in the steep slope of Mt. Skuleberget at a level of $+120 \mathrm{~m}$, which is the level of the first Littorina sea level peak at $7000 \mathrm{C} 14$-yrs BP. This implies a minor retardation in the rapid shorelevel displacement (relative uplift), providing time enough for a littoral cave to be eroded.

\section{From parallel concepts to unified theory}

The earliest observation of postglacial fracturing and interpretation in terms of earthquake origin come from De Geer in 1879 (De Geer, 1940, p. 124). De Geer observed that big angular blocks were sometimes concentrated in the end-moraines. He termed such moraines "seismic moras".

In 1929, von Post published interesting data from Säffle in SW Sweden. Old drawings (dated 1915) from the clay pit of Älvängen record extensive sedimentary deformations in the form of folds and faults (von Post, 1929). The site was later revisited by Mörner (Mörner, 2003, p. 256).

Bergsten (1943) was the first to demonstrate that the block cave of Torekulla was a product of tectonics. A similar view was expressed for the Trollegator (Trollgatere) cave site (Mårtensson and Nilsson, 1971; Bergsten, 1976). Other observations and suggestions of a seismotectonic origin were given by Agrell (1981, 1982), Sjöberg (1987a), and Isacsson (1990).

In 1994, Sjöberg took his $\mathrm{PhD}$ at the institute of Paleogeophysics \& Geodynamics at Stockholm University on a thesis entitled "Bedrock caves and fractured rock surfaces in Sweden: occurrence and origin". He identified six possible causes to the cave formation: (1) glacial tectonics, (2) freeze and thaw processes, (3) methane venting, (4) postglacial unloading (and stress release), (5) hydrofracturing, and (6) seismotectonics. The external examiner (Dr. Douglas Grant from Canada) said: "I think you have identified all possible processes, and I cannot think of any others". In his thesis, Sjöberg (1994a) evaluated the possible processes against the characteristics of 53 pseudokarst caves distributed over almost the whole of Sweden. The result is given in Table 3. It shows that seismotectonics is the most probable origin for 52 sites (and possibly for the remaining one site, too). Therefore, seismotectonics emerged as the most probable origin of the Swedish fracture caves, block caves or boulder caves, whatever name we may use for these pseudokarst caves in the crystalline bedrock, or within heaps of loose angular blocks. 
This was a major step forward in the understanding of Swedish non-karstic cave formation. It marked a paradigm shift in Swedish speleology.

Table 3. Sjöberg's semi-quantitative analyses of possible mechanisms behind the formation of 53 Swedish fracture and block caves (Sjöberg, 1994a).

\begin{tabular}{|l|c|c|c|}
\hline \multicolumn{1}{|c|}{ Process } & Impossible & Possible & Probable \\
\hline Glacial tectonics & 37 & 15 & 1 \\
\hline Frost deformation & 30 & 20 & 3 \\
\hline Methane venting & 40 & 11 & 2 \\
\hline Stress release & 10 & 29 & 14 \\
\hline Hydro-fracturing & 10 & 30 & 13 \\
\hline Seismotectonics & 0 & 1 & 52 \\
\hline
\end{tabular}

\section{A paradigm shift in Swedish seismology}

In the 1950s and 1960s, the Fennoscandian Shield was generally assumed to be of exceptional stability. Shoreline diagrams by Nilsson (1968) in Sweden and Hyyppä (1966) in Finland were claimed as evidence of this stability. However, Mörner (1979, 1980) and Donner (1980) demonstrated that those diagrams are no longer tenable.

In the $1960 \mathrm{~s}$, two major steps forward were made: (1) the repeated levelling identified irregularities (Asplund, 1968; Mörner, 1977a), and (2) C14-dated shorelines identified the presence of tectonic faultlines where the uplift isobases were bent (Mörner, 1969, 1977a).

In the 1970s, there were several important events: (1) the project on "postglacial earth movements" was initiated in 1973 as a part of the International Geodynamics Project (GDP), (2) because of the achievements within the project (Mörner, 1975), the international GDP group asked Mörner to organize an international conference in Sweden, (3) this conference was held in Stockholm in 1977 together with a field-excursion through southern Sweden (Mörner, 1977b, 1980), (4) Mörner (1977c) reviewed uplift irregularities and traces of possible paleoseismic events in Sweden (it seems that this was the first time the word "paleoseismic" was used), (5) Lundqvist and Lagerbäck (1976) published the first account of the Pärve Fault in northern Sweden, (6) Mörner (1978) published the first account on paleoseismics in the Stockholm area, (7) Mörner became the leader of the INQUA Neotectonics Commission and started issuing the Neotectonics Bulletin, which became an international source for the evolution of the understanding of neotectonics and paleoseismics. The Bulletin came out in 19 annual issues from 1978 to 1996. Mörner (1985) summarized available solid rock evidence, geomorphic evidence, sedimentological evidence and geophysical evidence indicating paleoseismic events in postglacial time. Additional observational data followed from sedimentary data (e.g., Mörner \& Tröften, 1993; Tröften, 1997), block cave generation (Sjöberg, 1994a) and bedrock faulting (Lagerbäck, 1990; Mörner, 1990).

In 1991, Mörner presented a mechanism for the interpretation of the observation that the deglacial period was characterized by frequent highmagnitude seismic events, whilst the present period is characterized by low to moderately low seismicity. He proposed (Mörner, 1991) that the rate of glacial isostatic uplift with rapid extensional forces in the vertical, radial and tangential dimensions initiated the high seismicity during deglaciation when the rate of uplift peaked and amounted to tens of $\mathrm{cm}$ per year (0.5 to $1.0 \mathrm{~mm}$ per day). This is illustrated in Fig. 5 .

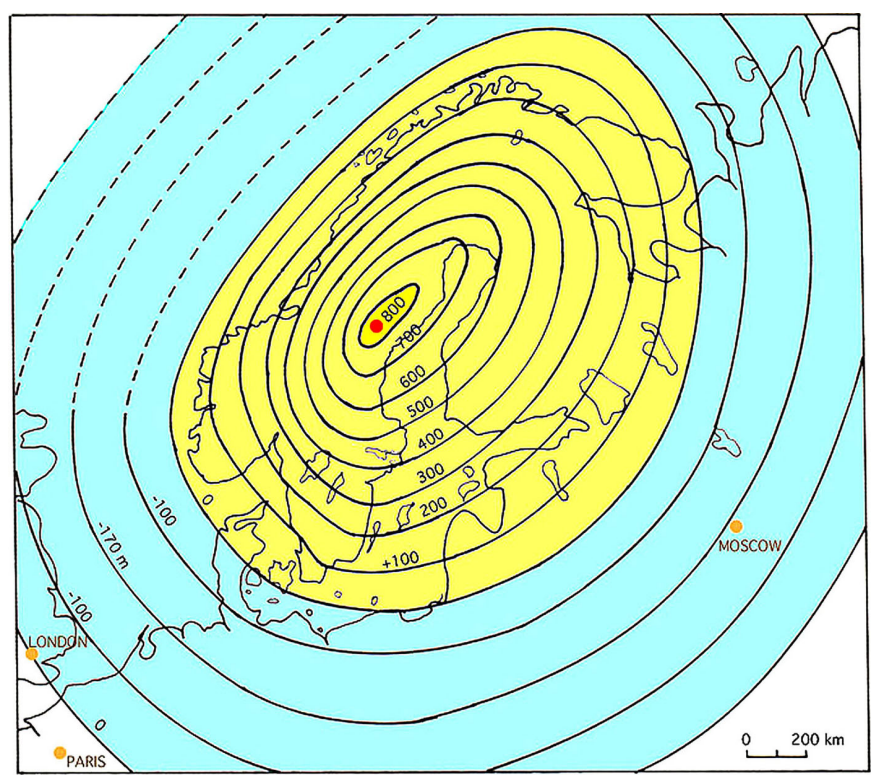

Fig. 5. Uplift of the Fennoscandian shield in the last 13000 years with contours in hundreds of meters of total uplift (from Mörner, 2003), giving rise to extension in the vertical, radial and tangential directions (Mörner, 1991).

In 1999, we felt ready for an international demonstration and discussion of our field data on seismotectonics and liquefaction (Mörner et al., 2000). An international excursion was organized (Mörner, 1999). It gave a thorough profile across the whole of Sweden from Umeå in the north to Båstad in the south. The excursion was attended by 40 specialists from all over the globe. The discussions were very fruitful, and lay the ground for extended analyses (Mörner, 2003).

Our working methodology was novel in the combination of fault data, sedimentary data, liquefaction structures, turbidite levels, varve chronology and tsunamite data (Mörner et al., 2000; Mörner, 2003, 2011). Magnetic grain rotation was also documented (Mörner \& Sun, 2008).

\section{A unified picture takes form}

As an outcome of the description of the Boda cave by Sjöberg (1994a), we were able to force the nuclear waste handling organization to finance a major research project on the Boda cave and related phenomena in the surrounding areas (Mörner et al., 2003).

A group of international experts (Professor Franck Audemard from Venezuela on liquefaction, Doctor Sue Dawson from Scotland on tsunami deposits and Professor Andrej Nikonov and Doctor Dmitri Zykov from Russia on block motions and seismicity) joined our research group at the Institute of Paleogeophysics \& Geodynamics at Stockholm University in 2000-2001.

The Boda cave was investigated and documented in detail. Thanks to the varve chronology, the creating earthquake could be dated at varve year 9663 BP 
(Mörner, 2003, 2013a, 2016a). It was linked to a major liquefaction event deforming sediments over an area of at least $80 \times 40 \mathrm{~km}$. It also set up a tsunami wave of at least $12.5 \mathrm{~m}$ height that was recorded over an area of $125 \times 30 \mathrm{~km}$. A turbidite was spread over the seafloor over a distance of $210 \times 40 \mathrm{~km}$ right in the annual varve of varve-year 9663 BP. Simultaneously, fracture caves and block caves were created and recorded over an area of $50 \times 50 \mathrm{~km}$. The primary fault has a scarp height in the order of 10-20 m. All this speaks clearly of a causation earthquake of $\mathrm{M}>8$ (Mörner, 2003), later fixed at M 8.5-8.6 (Mörner, 2017a).

The Boda cave investigation (Mörner et al., 2003) probably represents one of the most well-documented paleoseismic events in the world. It is thus the "core stone" for the formation of a unified picture of the mechanisms, characteristics and distribution of paleoseismic events in Sweden (Mörner, 2003; 2013b; 2016b, 2017a).

\section{International anchoring}

The above-mentioned international excursion in 1999 marked an important step in our formulation of the concept of a high-seismic activity in Sweden in former times (Mörner, 2003).

As a part of the $33^{\text {rd }}$ International Geological Congress in Oslo in 2008, we organized an excursion on Paleoseismicity and Uplift of Sweden in two parts: A, from Umeå to Stockholm, and B, from Stockholm to Båstad (Mörner et al., 2008; Sjöberg, 2008). It marks another key point in our studies.

In 2011, Mörner \& Sjöberg (2011) organized and hosted the Second International Conference on Granite Caves in 2011. It offered another occasion to direct the limelight on Swedish fracture caves and block caves. The guidebook (op. cit.) provides a representative illustration of various forms of "granite caves" in Sweden.

\section{SCREE DEPOSITS}

In his study of pseudokarst caves in Sweden, Sjöberg (1994a) included "caves in collapsed rock walls" as his "type 2" caves, and identified 21-23 of them. In the present SSF database, there are 33 scree accumulations registered. The distinction between talus deposits successively accumulated over time and the sudden breaking-off and falling down of huge rock masses is sometimes a fine one. In the first case, it is a matter of time and gravity. In the second case, there must be a release force, which seems logical to ascribe to seismic ground shaking (at least, nowadays, when this process has become well documented all over Sweden).

The sites Pyhävaara, Slåtterdalsgrottan and Ulorna (Sjöberg, 1994a, Figs. 26, 27, and 29), indeed, seem to represent momentous breakings-off of huge rock volumes, which are likely to have been triggered by paleoseismic events. The movement of the Pyhävaara scree can be directly connected with the Lainio Fault movement (Lagerbäck \& Witschard, 1983), which strongly supports the conclusion of Sjöberg (1994a).

In association with the $9663 \mathrm{BP}$ paleoseismic event in the Hudiksvall area, huge scree masses were detached at Blackåsberget and Storberget (Mörner et al., 2003, p. 109-111), hosting caves. A characteristic feature observed was that the scree accumulations at the foot of the scarps were not located at the logical (gravitationally straight-down) position, but lay tens of meters outside, as though moved by an extra ground shaking motion (i.e., paleoseismics). The Blackåsberget rock scarp and scree are shown in Fig. 6.

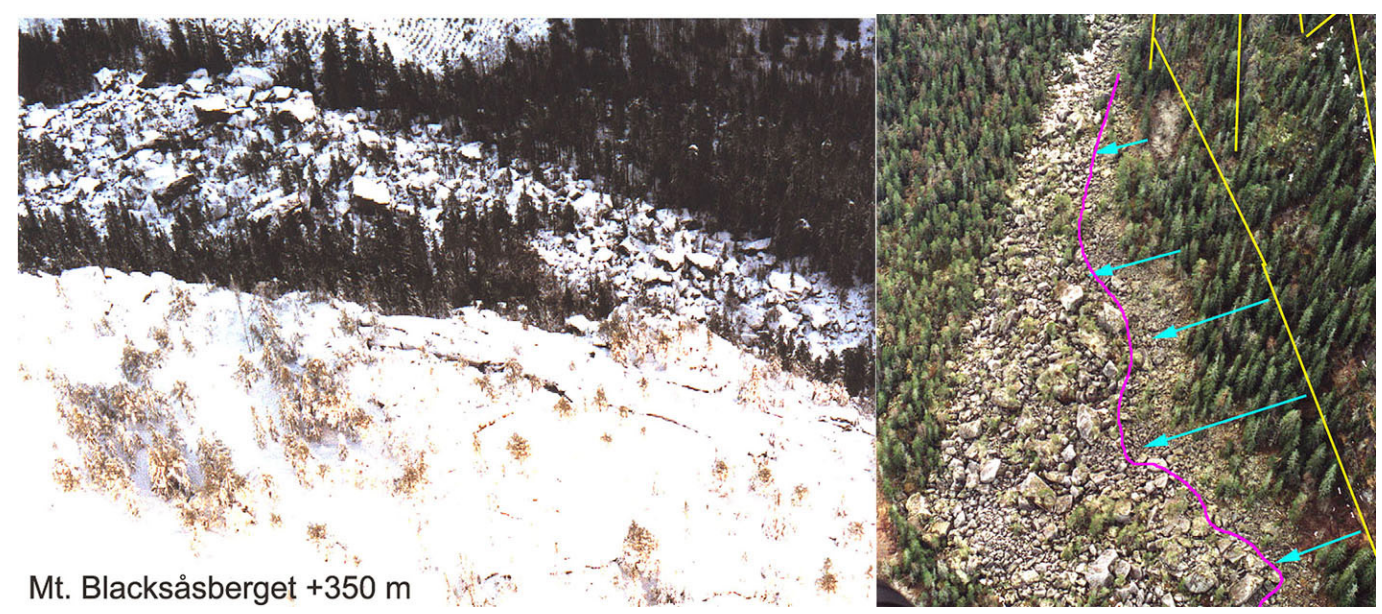

Fig. 6. The Mt. Blacksåsberget bedrock scarp is traversed by slope-parallel fractures with a big-boulder scree accumulation beneath, hosting caves (modified from Mörner et al., 2003; Sjöberg, 1994a). The scarp is high and steep and strongly fractured (left). The scree has not just fallen down gravitationally, but also been moved tens of meters laterally (blue arrows to the right) due to earthquake forces.

The Eastern Klövberget caves occur in a huge scree deposit (Fig. 7). Here we are able to demonstrate that the entire mass moved in one big scree unit, the movement of which is most likely to have been initiated by a strong earthquake. The simultaneous mass movement is indicated by the preservation of the original fracture patterns in the scree masses (Fig. 7). According to Mörner \& Sjöberg, (2011; Stop 6 of the Local Excursion) this may imply a novel model of proving that a scree moved as one huge unit in response to an earthquake.

It should be stressed that numerous scree accumulations, some of which may contain block caves, represent successive gravitational talus movements of rock fragments, and are of an aseismic origin. 

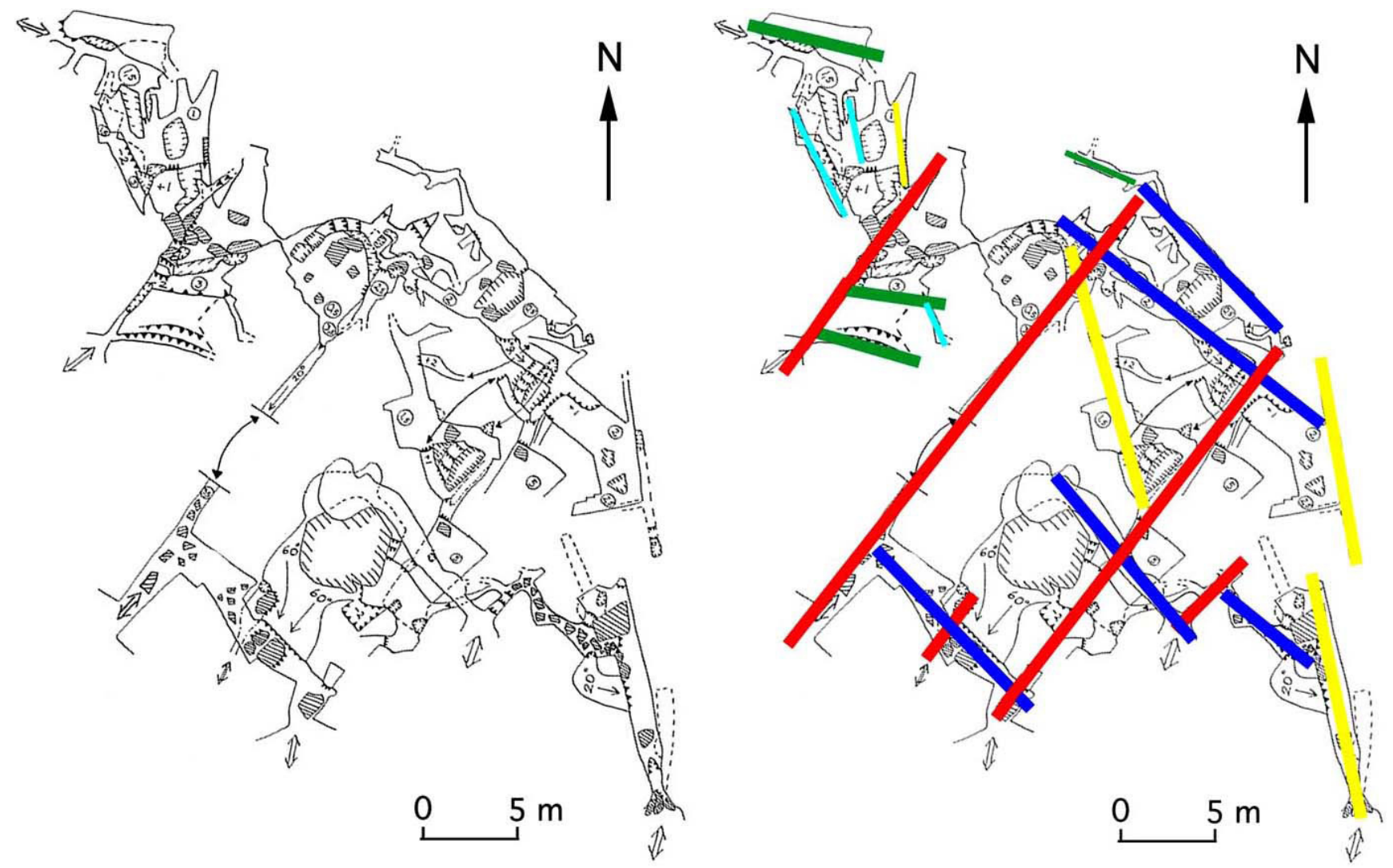

Fig. 7. The Eastern Klövberget caves occur in a huge scree accumulation (from Mörner \& Sjöberg, 2011). Because the fracture pattern can still be identified in the scree masses, the entire scree must have moved in one huge mass. This is indicative of a paleoseismic origin.

\section{METHANE VENTING TECTONICS (MVT)}

Björklund (1990) was the first to suggest that methane venting might have something to do with the fractured bedrock observed both in Finland and Sweden. It was followed by general discussion of this concept (Mörner, 1993), and a comprehensive study of granitic caves in Sweden (Sjöberg, 1994a). Both authors appreciated the possibility of this mechanism, but neither was then able to present any clear observational facts. Definite evidence came with the study of the Boda Cave (Mörner, 2003) and the comprehensive presentation on Methane Venting Tectonics (Mörner, 2017b, c).

Mörner recognized at least 13 sites in Sweden, and 1-2 sites in Finland of methane venting tectonics (Mörner, 2017b, 2017c). Out of the 13 Swedish sites, 10 date from the late glacial period (with 4 from the 9663 BP event) and 3 from the Late Holocene.

Figure 8 illustrates our interpretation of methane venting tectonics triggered by the $9663 \mathrm{BP}$ earthquake, and the deformational structures recorded at the site of deformation at the Boda Cave (Mörner at al., 2003; Mörner, 2017b).

North of Hudiksvall, lies the Skålboberget site (Mörner et al., 2003, p. 105-109; Sjöberg, 2009; Mörner, 2017a-c; ). It refers to a $25 \mathrm{~m}$ high cone (with a base of about $110 \times 170 \mathrm{~m}$ at an elevation of $+32 \mathrm{~m}$ ) consisting of angular blocks, and with gigantic blocks at the top (with volumes in the order of $8,000 \mathrm{~m}^{3}$ ). A minor cave at the base includes rounded beach boulders (Fig. 9), indicating that the cone formation occurred after the uplifting beach was at sea level at 3200 BP (Mörner, 2003, p. 105-109), because there
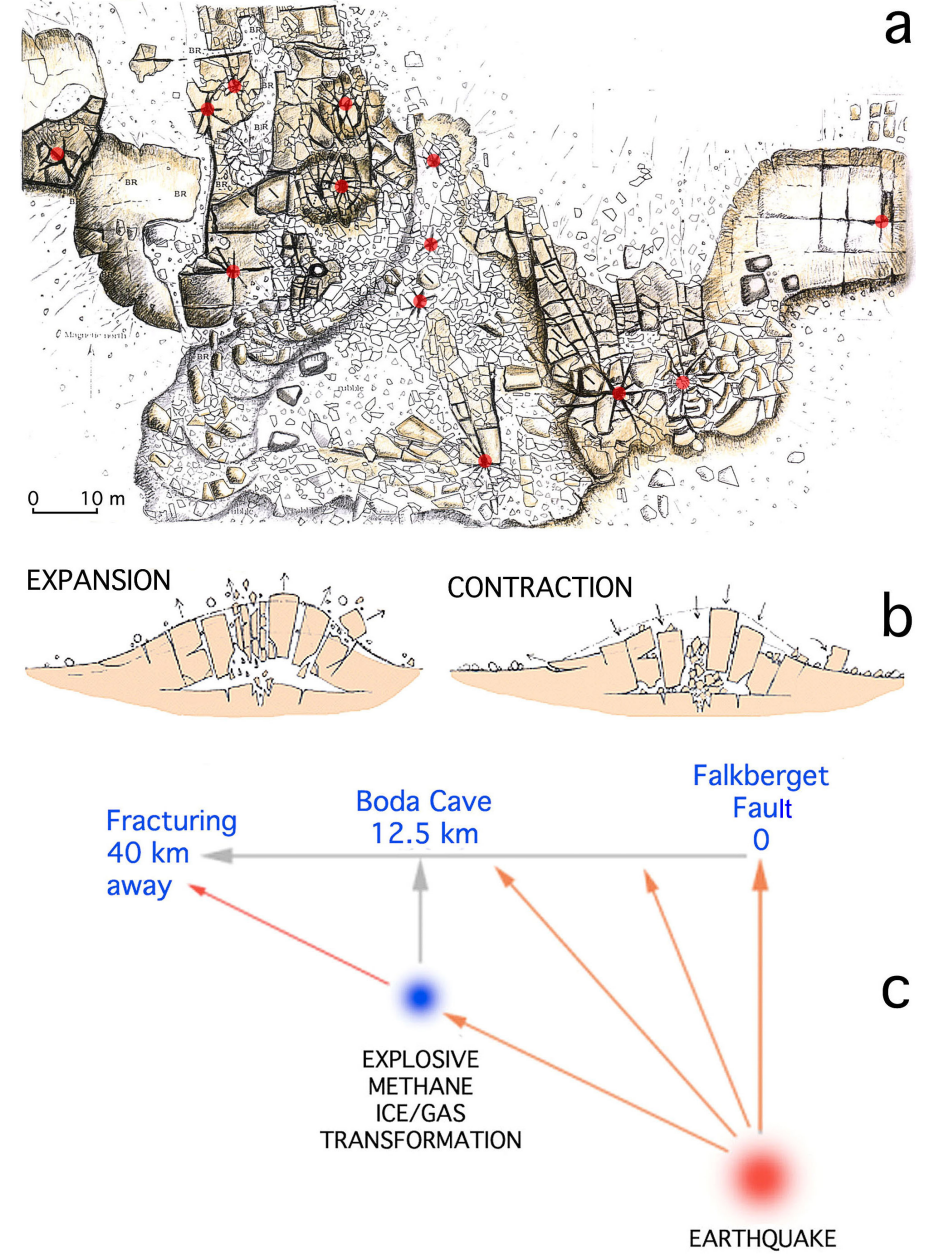

Fig. 8. Map of the Boda Cave surface (a) with 13 minor centres of deformation (red dots), the mode of initial expansion followed by contraction (b) and model (c) of interaction between seismic ground shaking and methane venting (from Mörner et al., 2003; Mörner, 2017b). 
are no traces of marine abrasion of the cone itself. A $12 \mathrm{~m}$ high tsunami wave was generated in direct association with the bedrock deformation (Mörner \& Dawson, 2011; Mörner, 2017c). The tsunamite layer was dated at older than 2,411 $\pm 50 \mathrm{cal}$. yrs BP. The venting of methane affected the lake environment, and most C14-dates were strongly affected by dead carbon (Mörner, 2017c), with the largest deviation being $18412 \pm 378$ cal. yrs BP instead of 2900 BP (the time of the event). This contamination provides a good confirmation of dead carbon from the methane venting. The methane venting tectonic took place when sea level was at $+26 \mathrm{~m}$, which occurred at 2900 BP (Mörner, 2017c, p. 9).

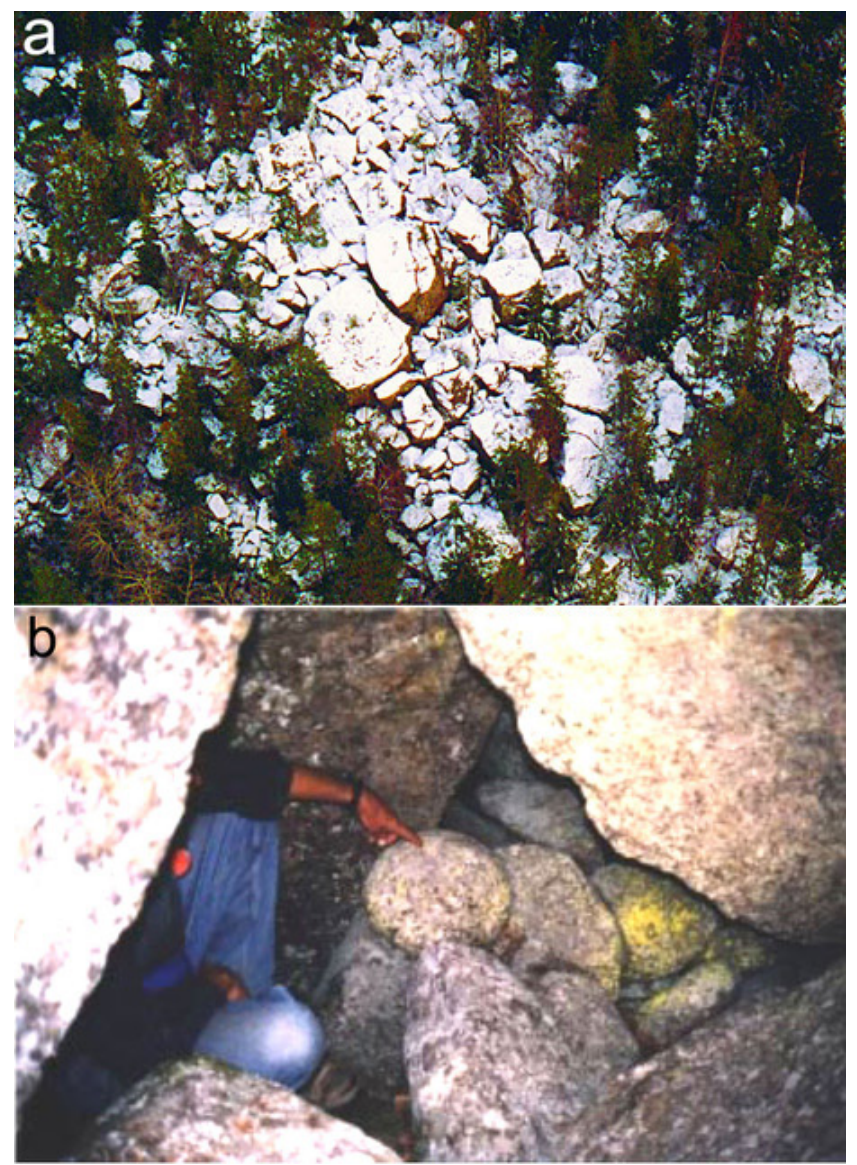

Fig. 9. The Skålboberget site represents the deformation at an explosive methane venting (from Mörner et al., 2003; Mörner, 2017b). The cone of blocks is $25 \mathrm{~m}$ high, and has some gigantic blocks at its top (a). The block cone contains several caves; one at the base contains rounded littoral boulders (b), indicating a deformation in Late Holocene time when sea level had fallen to $+26 \mathrm{~m}$ at $2900 \mathrm{BP}$.

Kvarnberget refers to a site south of Stockholm, which can only be understood in terms of violent methane venting (Mörner, 2017b, c). It was first observed by Sjöberg (2009), structurally investigated in detail by Mörner (Mörner \& Sjöberg, 2011) and fully presented in Mörner $(2017 b$, c). Later field studies in 2018 (Mörner, unpublished) have further pinpointed the age determination at about $2900 \pm$ $100 \mathrm{BP}$

Kvarnberget is a $25 \mathrm{~m}$ high cone of blocks broken loose from the solid bedrock beneath. The block cone is full of minor caves. At the top there are two gigantic blocks (Fig. 10). The cone is surrounded by erosional troughs continuing in a $10-15 \mathrm{~m}$ deep river canyon cut in clay deposits, which ends in a huge delta (of about
$400,000 \mathrm{~m}^{2}$ ) at the level of $+15 \mathrm{~m}$ (Mörner, 2017c). This level (with a lot of fine structures documented in 2018) corresponds in age to about 2800-3000 BP (Mörner, unpublished).

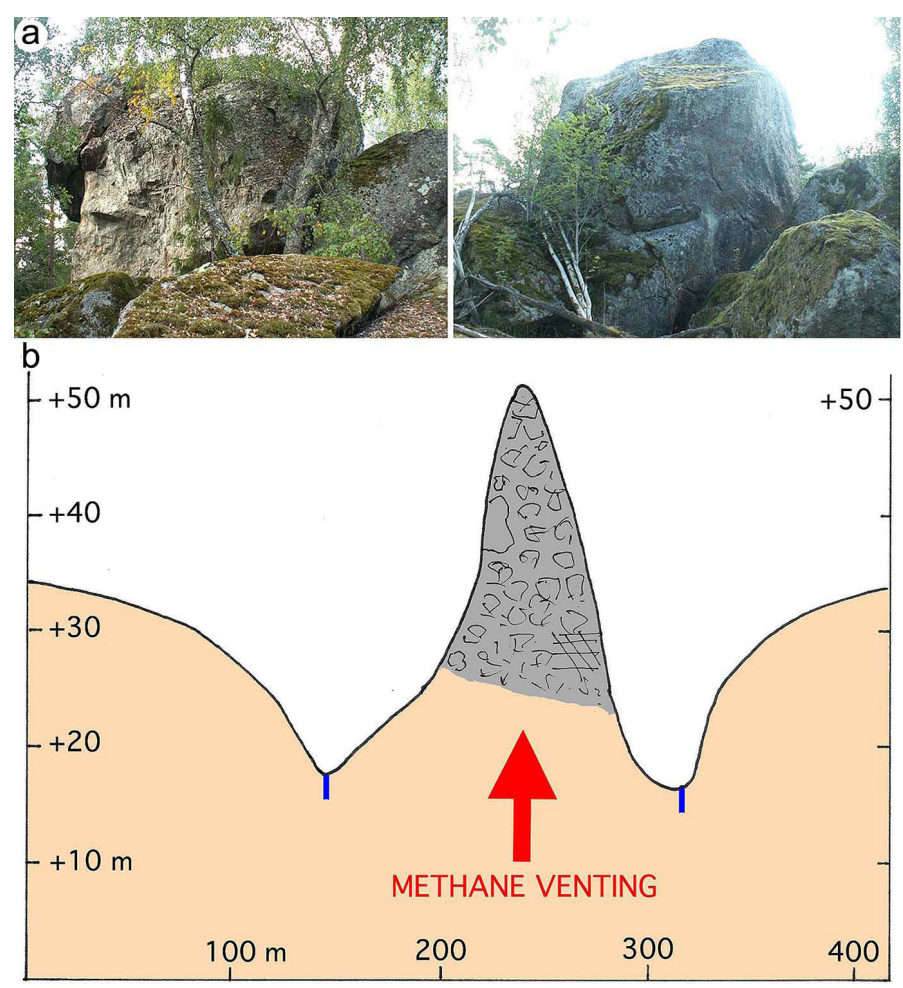

Fig. 10. Kvarnberget, a $25 \mathrm{~m}$ high cone of huge blocks hosting caves (from Mörner \& Sjöberg, 2011; Mörner, 2017a, b). At the top of the block cone there are some gigantic blocks (a). The cone is surrounded by depressions (b), which, via an $800 \mathrm{~m}$ long and 10-15 m deep canyon cut into clay deposits, end in a huge delta at $+15 \mathrm{~m}$. This implies that the methane venting episode took place at about 2900 BP.

\section{SHORE CAVES}

Shore caves are another type of pseudokarst. They are formed by littoral wave actions, and have little or no relation to seismotectonics. Hence our discussion is brief.

De Geer (1902) and Lindström (1902) were both pioneers in the study of shore caves. Whilst De Geer correctly understood that shore caves were predominantly formed by stones and blocks moved by the littoral wave action, Lindström advocated streaming water. Munthe (1920) gave a general account on the occurrence of "shore caves" (Swedish: strandgrottor) in Sweden.

The "tunnel-cave" (Sjöberg, 1986a) is a special type of shore cave abraded along a single sub-vertical fracture (Fig. 3). The caves have a typical well-rounded crosssection. In a number of papers, Sjöberg addressed the occurrence and formation of these caves (Sjöberg, 1981, 1982, 1983a, b, 1984, 1985, 1986b, c, 1987a, $1991,1994 b)$. He found that the formation of these caves needed fractures that were directed toward the sea (with a long relative fetch) and the prevailing winds. Furthermore, the volume of abraded rock was, at the time of formation, depending on sufficient access of abrading material in the form of washed till.

In northern Sweden, the rate of uplift is still very fast: up to $10 \mathrm{~mm} / \mathrm{yr}$ with an exponentially increasing rate back in time (Mörner, 1979). This means that 
littoral erosion can only have had a short duration of activity at a single elevation when passing through the shore zone. Nevertheless, Sjöberg (1982, 1983b, 1984, 1987a, 1991, 1994b) reported numerous tunnel caves hanging in the hillsides inland, far above present sea level (Fig. 4). They seem to date from the Littorina Sea period of the Baltic and to represent minor retardations in the relative sea level rise, due to the effect of eustatic oscillations (Mörner et al., 2008). At Lidberget, south of Umeå, there are at least five good examples of littoral caves (Sjöberg, 1982, 1991). They are concentrated at 90-110 m above sea level, and are associated with an extensive fracture system (Mörner et al., 2008, Fig. 26), formerly filled with dykes of dolerite (Sjöberg, 1983b).

Some caves and abraded depressions may have got their primary erosion by water-flow under high hydrostatic pressure along fractures and bedrock irregularities in subglacial position (Mörner, 2003, p. 238).

\section{CAVE EXAMPLES}

After the above theoretical review of Swedish pseudokarst caves, we now turn to a representative "gallery" of some of the cave structures actually recorded.

\section{The Boda Cave}

The Boda Cave at Iggesund represents a former bedrock hill deformed into a seemingly chaotic field of angular blocks (Fig. 11). The sub-surface contains a system of cave passages of a total length of 2,633 m. The cave system was skilfully mapped by Alf Sidén. His map (Fig. 12) agrees perfectly well with our air photography (Fig. 11) as further discussed in Mörner et al. (2003). Though the surface may look chaotic (Fig. 11), a closer analysis reveals that much of the surface remains more or less in place (as seen in glacial striae and rock veins). This indicates that the deformation took place in two steps; first a nearly "explosive" extensional deformation, and second a falling-back contraction as illustrated in Fig. 13. This mechanism (Mörner et al., 2003) also seems to apply to most of the other bedrock block caves in Sweden.

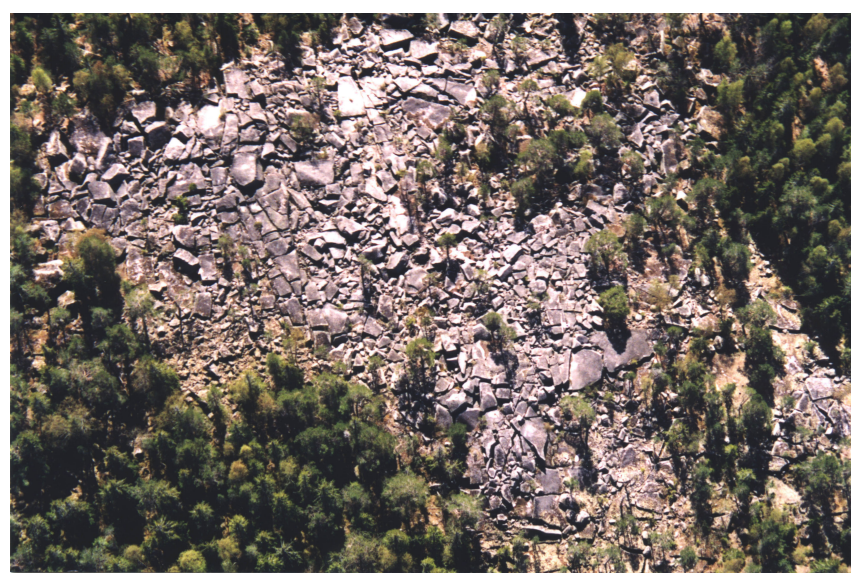

Fig. 11. The Boda cave as seen from the air: a hilltop transformed into a large field of huge, angular blocks from the underlying crystalline bedrock (from Mörner at al., 2003).

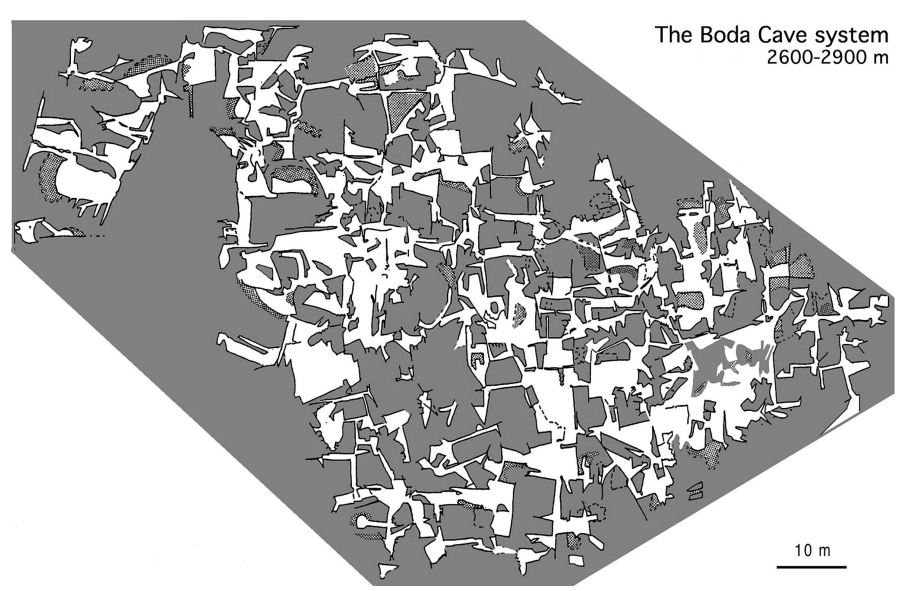

Fig. 12. Map of the sub-surface caves and passages of a total length of $2633 \mathrm{~m}$ (from Mörner et al., 2003). The caves have been followed $25 \mathrm{~m}$ down, but the roots of the cave seem to go down 100-150 m.
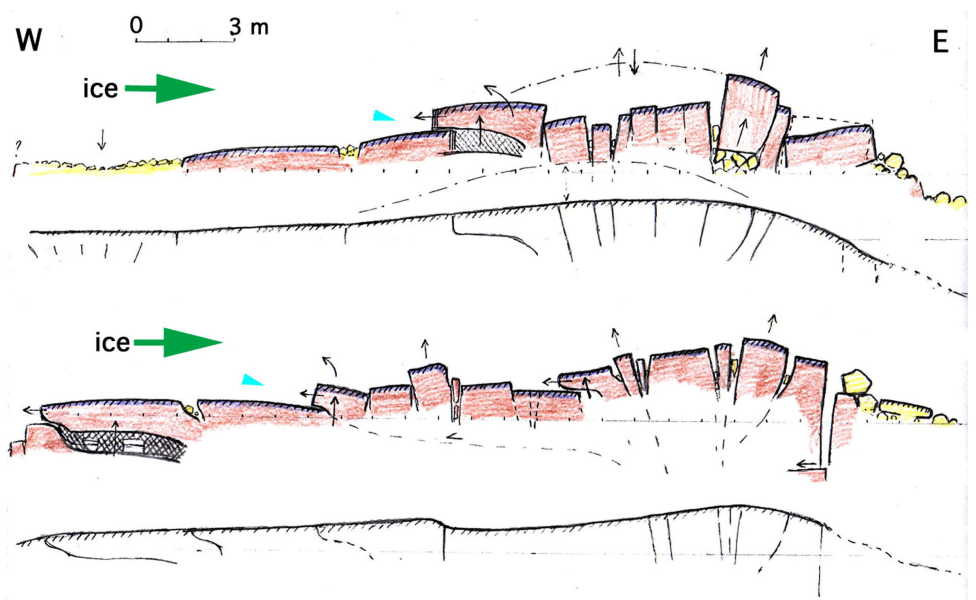

Fig. 13. Mode of deformation as recorded in two cross-profiles (from Mörner et al., 2003). It shows the interaction of an extension force deforming the old bedrock surface into blocks moved upwards and outwards, followed by a contraction force with blocks falling back

The cave system goes down $25 \mathrm{~m}$ below the surface. The root fractures of the cave system seem to reach at least 100-150 $\mathrm{m}$ below the surface, however, judging from our deep drillings. The surface gives an impressive view of huge angular blocks where one side is a smoothly polished bedrock surface from the pre-deformational glacial surface (Fig. 14). This, too, is a characteristic criterion of Swedish bedrock block caves. Figure 15 shows a bedrock disc trapped in an open fracture, vividly illustrating the mode of deformation: extensional fracture opening and throwing out of the disc, followed by a subsequent contraction trapping the disc when it fell back.

From the violence of deformation recorded at the Boda Cave, one might suspect that it was formed close to the epicentre of a high-magnitude earthquake. This is not the case, however. The epicentre lies $12.5 \mathrm{~km}$ to the NE. Therefore, methane venting tectonics is likely to have been an additional or primary process (Fig. 8), as further discussed in Mörner et al. (2003) and Mörner (2017b).

\section{Alf's Gryt}

Alf's Gryt is another bedrock cave formed by the 9963 BP paleoseismic event (Mörner et al., 2003). The sub-surface cave includes deltaic deposits of sandy silt with grits, sucked into the cave when extensional 


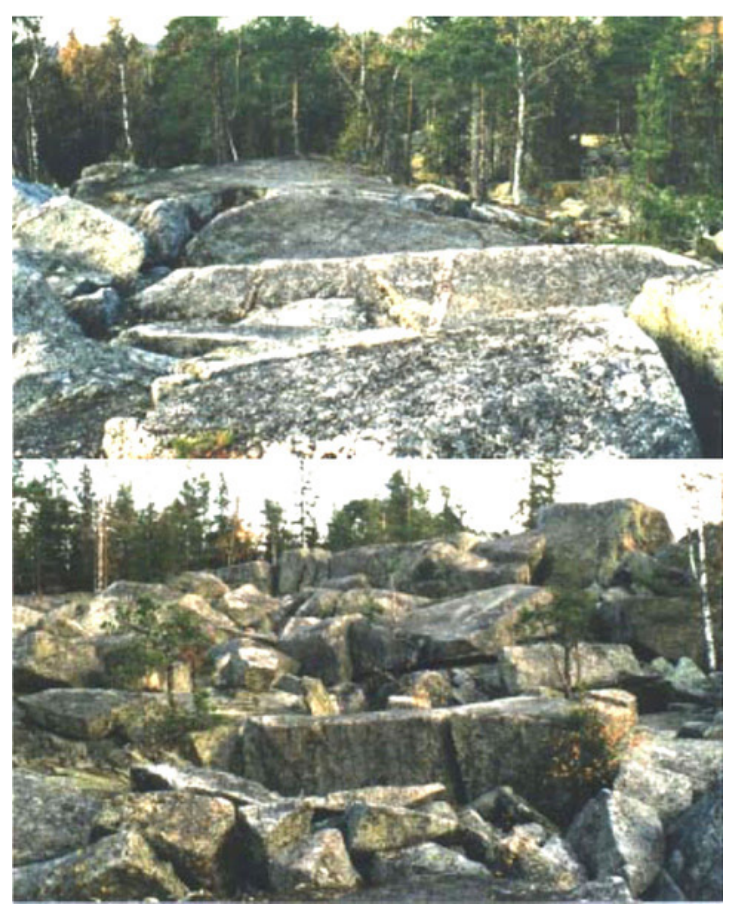

Fig. 14. The surface of the Boda cave area (from Mörner et al., 2003; Mörner, 2017c); partly a chaotic block field (below) and partly huge blocks fractured loose from the bedrock and "vibrated" more or less in position (above).

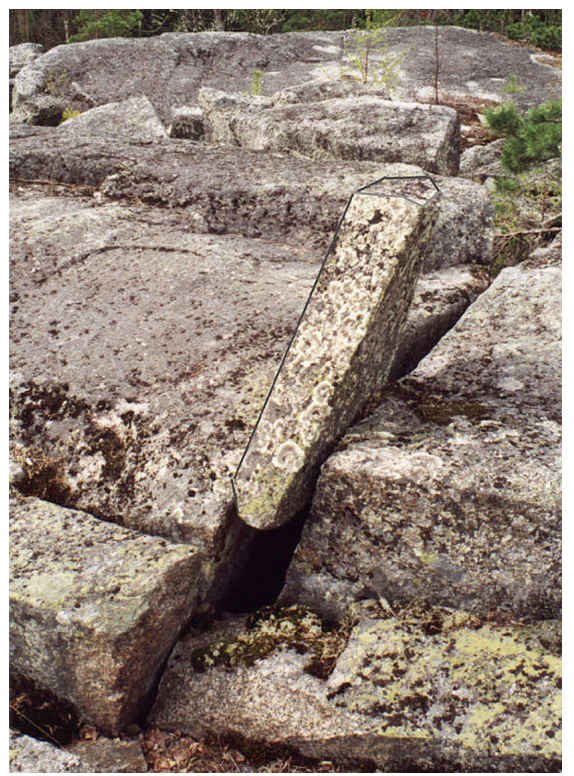

Fig. 15. A bedrock disk stuck right in its falling-back motion by a contraction fracture (from Mörner et al., 2003). This provides firm evidence of an extensional opening followed by contraction. To throw a piece of rock up into the air can only be achieved by a violent seismic event.

forces lifted and fractured the roof (Fig. 16). Violent methane venting tectonics may have been the driving force (Mörner, 1017c).

\section{Mehedeby}

Site Mehedeby (Sjöberg, 1994a) refers to a bedrock hill totally fractured into huge angular blocks (Fig. 17). This can only have been achieved at a major earthquake. An age of about 10,000 varve years BP was assigned (Mörner, 2003, 2017c, d).

\section{Gillberga Gryt}

Gillberga Gryt refers to a fracture and block cave about $100 \mathrm{~m}$ long. It is described in detail by Sjöberg
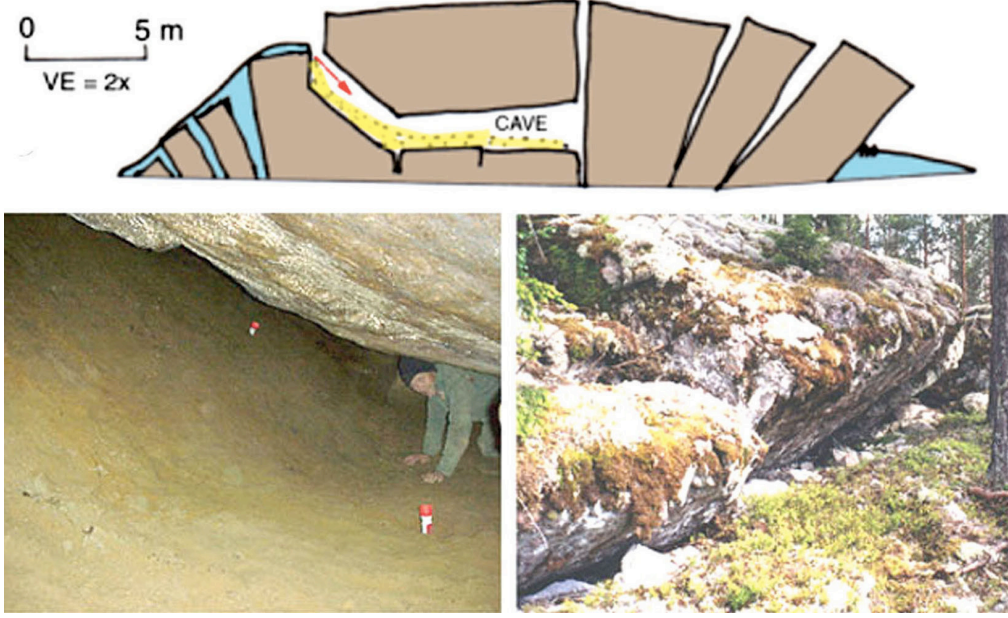

Fig. 16. Alf's Gryt; a cave formed at the $9663 \mathrm{BP}$ paleoseismic event (from Morner et al., 2003; Mörner, 2017b). A bedrock area of about $60 \times 70 \mathrm{~m}$ was fractured into blocks, which were moved anti-gravitationally upwards (top profile and lower right). This forced sediments to become sucked into the cave and deposited in a deltaic manner (lower left).

(1994a), with some additional notes in Mörner (2003, 2017c, d). It was formed at a paleoseismic event at 10160 varve years BP. Fig. 18 gives a view of the block deformation. Explosive methane venting seems - totally or partly - to have been involved (Mörner, 2017c).

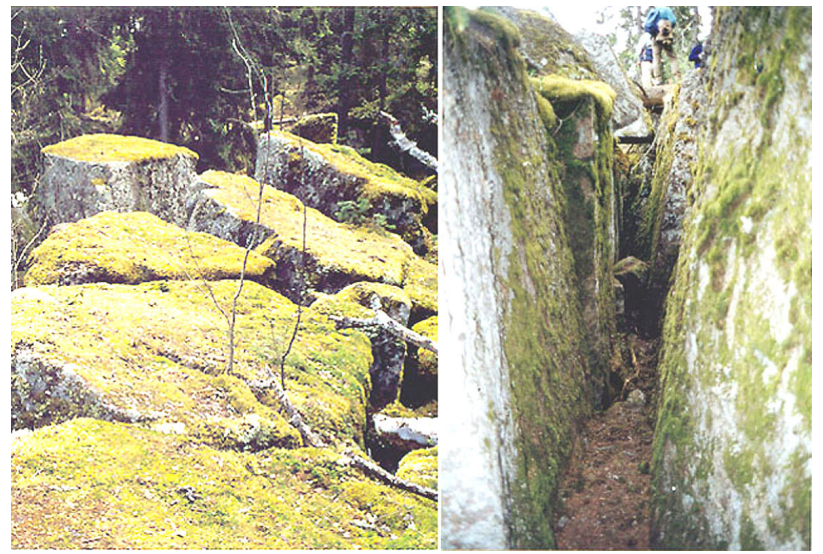

Fig. 17. Mehedeby (from Mörner, 2003; Mörner \& Sjöberg, 2011). The bedrock is cut up into large blocks with the fracture pattern still visible. Caves occur underneath and between the blocks.

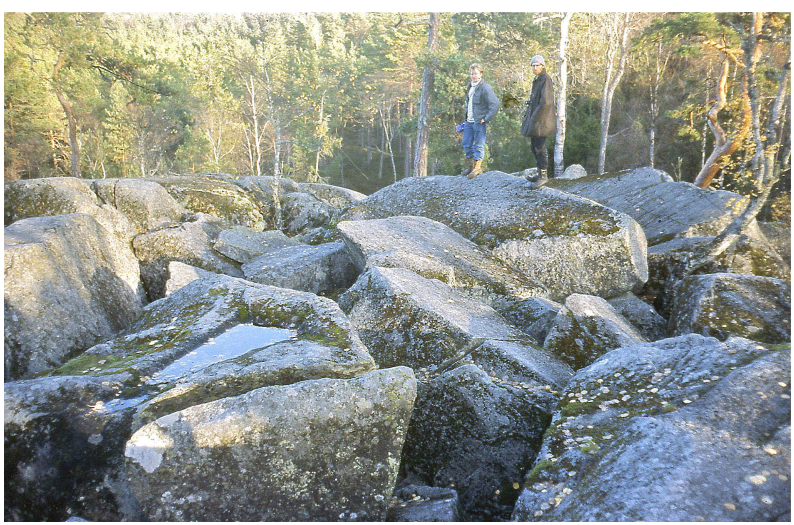

Fig. 18. Gillberga Gryt (Sjöberg, 1994a; Mörner, 2003) deformed by an earthquake at about 10160 BP. The deformation produced a heap of big blocks with quite large caves underneath.

\section{Trollberget}

This site was investigated quite recently (Mörner $2017 b, c)$. It consists of huge angular blocks broken loose from a previous smooth bedrock surface, well 
striated and polished by glacial motions (Fig. 19). No doubt, it represents a severe deformation in postglacial time, maybe at around 10200 varve years BP. It seems to be a quite clear case of explosive methane venting tectonics (Mörner, 2017c).
Alternatively, Mehedeby, Gillberga Gryt, Trollberget and a few others may have been formed all at once at major paleoseismic event occurring at about 10000 varve years $\mathrm{BP}$ and amounting to $\mathrm{M} 8$ to $\mathrm{M}>8$ (Mörner, 2017d).

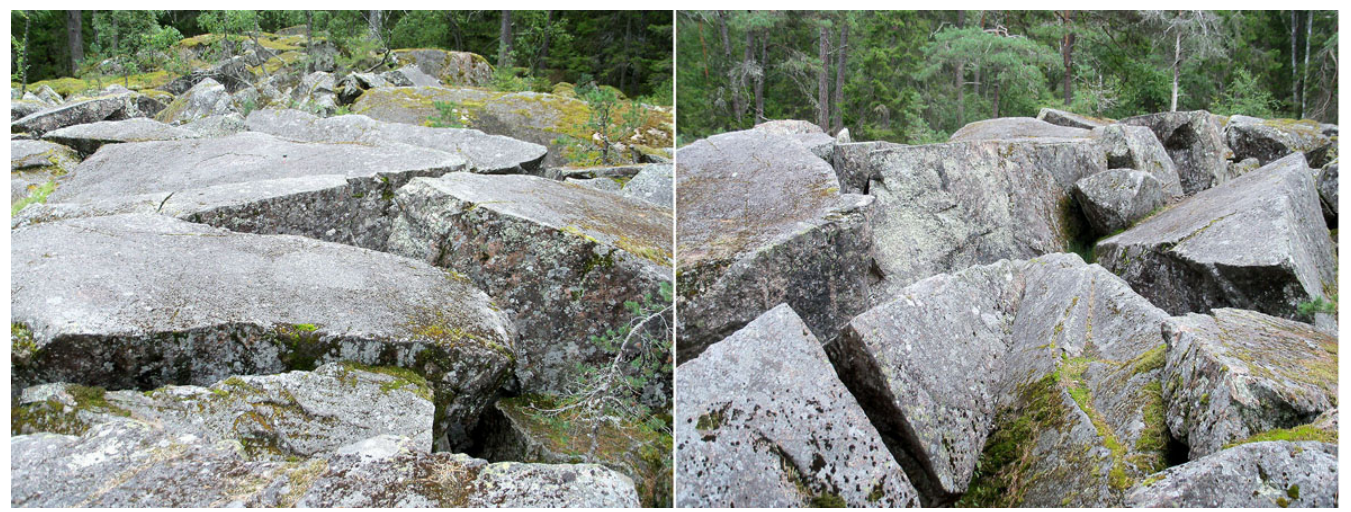

Fig. 19. Trollberget (from Mörner, 2017c); a site of quite violent bedrock deformation hosting several subsurface caves. The old glacially polished bedrock surface is well visible on the loose blocks, providing solid evidence that the deformation must have taken place in postglacial time.

\section{Pukeberg}

This is quite an interesting site (Sjöberg, 1994a; Mörner \& Sjöberg, 2011). The cave and its surrounding area were recently investigated in detail (Mörner, 2017e). It seems obvious that it was formed by a combination of earthquake forces and methane venting tectonics (Mörner, 2017c). The age of deformation is estimated at about 10300 varve years BP.

The Pukeberg cave lies inside a hill that was solid and glacially well polished at deglaciation, but is now totally deformed into huge blocks and open fractures (Fig. 20).

The mode of deformation is well recorded in Fig. 21. An initial opening of fractures allowed a well-rounded erratic block of $60 \mathrm{~cm}$ diameter to fall into the cave below. A subsequent partial contraction of the fault fractures now no longer allows a block of that size to pass.

\section{Other sites}

The bedrock block caves illustrated above just represent a selection of available sites. Several other sites are discussed in Sjöberg (1994a). Torekulla Kyrka and Trollegater, for example, are block caves of very similar type to those of Boda (Fig. 11), Gillberga (Fig. 18) and Trollberget (Fig. 19).
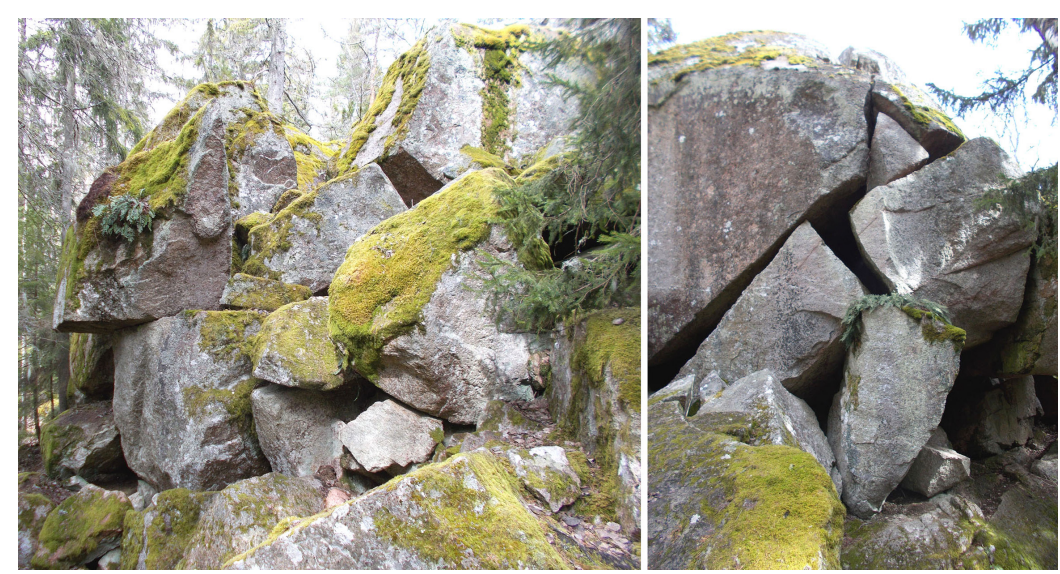

Fig. 20. Pukeberg (from Mörner, 2017e); a glacially formed solid bedrock hill is now strongly faulted and fractured with individual blocks moved laterally.

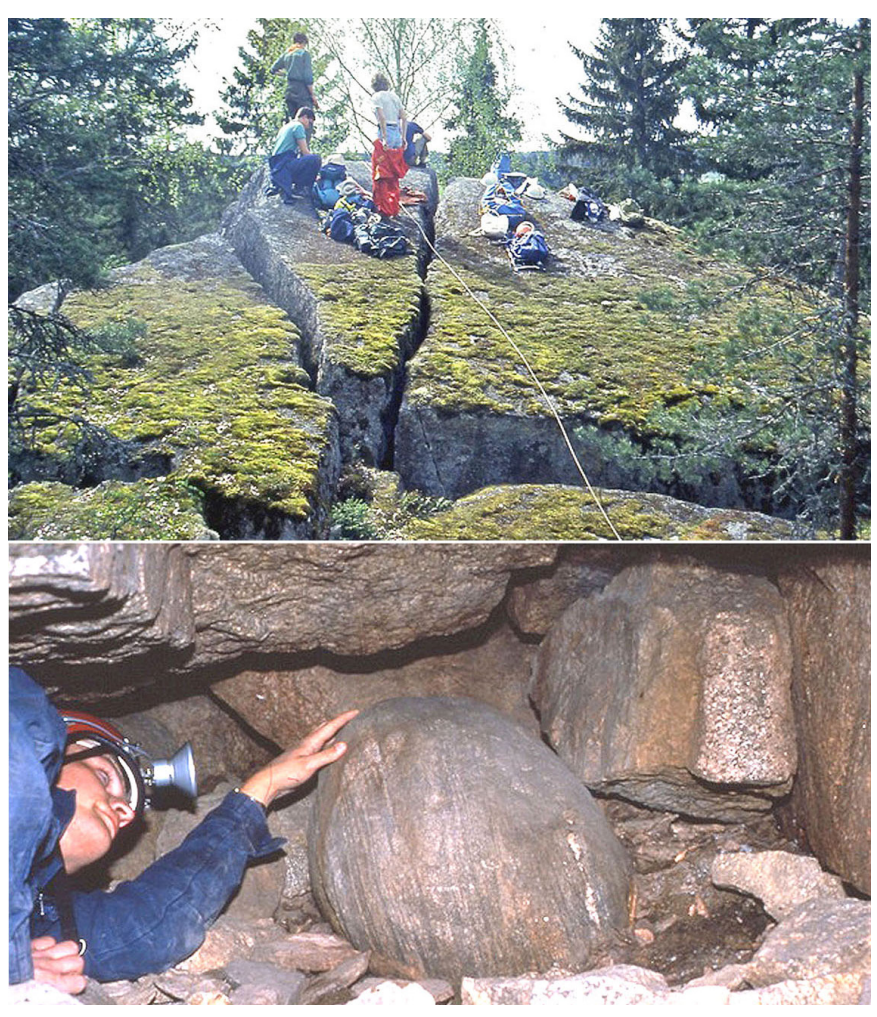

Fig. 21. The mode of deformation at Pukeberg (Sjöberg, 1994a; Mörner, 2017e); extension opened the fractures so that a $60 \mathrm{~cm}$ round erratic block could fall down into the cave below, followed by contraction so that the fractures above the cave are now far narrower than the size of the erratic block.

\section{COMPARISONS}

Block and fracture caves of a seismotectonic origin have been described in Finland (Mörner, 2010). In recent years there have been several reports on paleoseismic fracturing of the crystalline bedrock in northwest Russia (e.g., Rodkin et al., 2012; Shvarev \& Rodkin, 2017; Gorbatov et al., 2017; Nikolaeva et al., 2018). Cooper \& Mylroie (2015a, b) described "large fractures, and upon failure, large talus blocks, assisting pseudokarst cave development" from the 
northeast of USA. An international comparison of potential records of methane venting tectonics (MVT) is given in Mörner $(2017 \mathrm{~b}, \mathrm{c})$.

\section{CONCLUSIONS}

After the preceding reviews of Swedish cave history and the evolution of paleoseismic understanding, we can now sum up some of the main conclusions with respect to the origin of fracture caves and block caves in Sweden:

- Sweden has an excellent database of speleological objects (SSF, 2018). The vast majority of sites (1919 or $66.8 \%$ ) refer to fracture caves and block caves.

- The fracture caves and block caves (also known as boulder caves, bedrock caves or granite caves) have taken some time to be understood. With the thesis by Sjöberg (1994a), a seismotectonic origin became the most logical explanation. With the Boda Cave Project it became indisputable (Mörner et al., 2003).

- Methane venting tectonics has recently been proposed as the causational process of some heaps and cones of angular boulders (Mörner, 2003; $2017 \mathrm{~b}, \mathrm{c})$. The most surprising thing with some of those block caves and block concentrations is that they took place in Late Holocene time, with four events occurring at about $3000 \mathrm{BP}$.

- We trust we have now successfully joined the concept of fracture caves and block caves in Sweden with the concept of a high paleoseismic activity in deglacial time as well as in Holocene time into a unified theory, where we claim that the majority of those caves were formed by seismotectonic processes and sometimes by methane venting tectonics.

\section{ACKNOWLEDGEMENTS}

R.S. developed the understanding of Swedish caves. N.A.M. developed the understanding of neotectonics and paleoseismicity in Sweden. Both ideas merged at the Institute of Paleogeophysics \& Geodynamics at Stockholm University with the thesis by R.S. in 1994, where most fracture caves and block caves were explained in terms of paleoseismics. Most of the papers by Sjöberg can be found on ResearchGate and Linkedin, and those by Mörner on ResearchGate. Mörner's paleoseismic monograph of 2003 can be obtained directly from author (via mail order). The 2011 conference guidebook and Sjöberg's monograph on tunnel caves can be ordered from Sveriges Speleolog-Förbund. We acknowledge very fine and useful comments by Dr. Trevor Faulkner and Dr. Raúl Pérez López, which undoubtedly improved the paper.

\section{REFERENCES}

Agrell H., 1981 - Gillberga gryt - en senglacial sprickgrotta $i$ uppland. Grottan, 1981 (4): 28-29.

Agrell H., 1982 - Senaste nytt om Bodagrottorna. Grottan, 1982 (1): 22-25.
Asplund L., 1968 - Land uplift in Sweden: a preliminary study based on repeated levellings and mareograph data. Geographical Survey Office, Meddelande D2: 1-6.

Bergsten K.E., 1943 - En senglacial förkastning i Norra Östergötland. Meddelanden, Svensk Geografisk Årsbok 1943, 19: 1-16.

Bergsten K.E., 1976 - De lösa blockens urbergsgrotta. Grottan, 1976/1: 4-7.

Björklund A., 1990 - Methane venting as a possible mechanism for glacial plucking and fragmentation of Precambrian crystalline bedrock. Geologiska Föreningen i Stockholm Förhandllingar, 112: 329-333. https://doi.org/10.1080/11035899009452731

Cooper M.P. \& Mylroie J.E., 2015a-Pseudokarst and nondissolutional Caves. In: Glaciation and spelogenesis. Springer, Cham, p. 49-66.

https://doi.org/10.1007/978-3-319-16534-9_4

Cooper M.P. \& Mylroie J.E., 2015b - Caves and karst of New England and Eastern New York. In: Glaciation and spelogenesis. Springer, Cham, p. 121-130. https://doi.org/10.1007/978-3-319-16534-9_8

De Geer G., 1902 - Beskrifning till kartbladet Strömstad med Koster. Sveriges Geologiska Undersökning, Series Ac, 1.

De Geer G., 1938 - Jordbäuningar i Bromma. Svenska Turistföreningen 1938: 1-24.

De Geer G., 1940 - Geochronologia Suecica Principles. Kungliga Svenska Vetenskapsakademien. Handlingar, Band 18 (6): 367 p.

Donner J., 1980 - The determination and dating of synchronous Late Quaternary shorelines in Fennoscandia. In: Mörner N.-A. (Ed.), Earth rheology, isostasy and eustasy. John Wiley \& Sons, p. 285-293.

Dreimanis A., 1969 - Selection of genetically significant parameters for investigation of tills. Uniwersytet Adam Mickiewicz (Poznan) Zesyty Naukowe, Geografica, 8: 15-29.

Gorbatov E.S., Sorokin A.A., Marakhanov A.V. \& Larkov A.S., 2017 - The results of detailed palaeoseismological studies in the Kindo Peninsula area (Karelian coast of the White Sea). Problems in Engineering Seismology, 44 (3): 5-24.

Gustafsson T., 2007 - The Baltic Speleological Conference, the Island of Gotland, 2007.

Hyyppä E., 1966 - The Late-Quaternary land uplift in the Baltic sphereand the relation diagram of raised and tilted shore levels. Annals Academy Science Fenniae, Series A, III, 90: 153-168.

Isacsson G., 1982 - Strångberget - en studie $i$ grott. Grottan, 1982 (4): 34-39.

Isacsson G., 1990 - Neotectonic granite caves of Jämtland, central Sweden. Proceedings of the $4^{\text {th }}$ International Symposium on Pseudokarst, Praha, p. 32-37.

Lagerbäck R., 1990 - Late Quaternary faulting and Paleoseismicity in northern Fennoscandia, with particular reference to the Lansjärv area, northern Sweden. Geologiska Föreningen i Stockholm Förhandlingar, 112 (4): 333-354.

https://doi.org/10.1080/11035899009452733

Lagerbäck R. \& Witschard F., 1983 - Neotectonics in northern Sweden: geological investigations. KBS, Tecknical Report, 83: 58 p.

Lindström A., 1902 - Beskrifning till kartbladet Uddevalla. Sveriges Geologiska Undersökning, Series Ac. 3.

Linnaeus (Linné), C., 1732. Iter Lapponicus.

Lundqvist J. \& Lagerbäck R., 1976 - The Pärve Fault. A late glacial fault in the Precambrian of Swedish Lapland. Geologiska Föreningen i Stockholm Förhandlingar, 98: 45-51.https://doi.org/10.1080/11035897609454337 
Munthe H., 1920 - Strandgrottor och andra närstående geologiska fenomen. Kungliga Jordbruksdepartementets skrifter 38, Stockholm.

Mårtensson U. \& Nilsson L., 1971 - Trollgatera-eine Höhle in Granit Skandinaviens. Die Höhle, 22 (4): 120-127.

Mörner N.-A., 1969 - The Late Quaternary history of the Kattegatt Sea and the Swedish West Coast: deglaciation, shorelevel displacement, chronology, isostasy and eustasy. Sveriges Geologiska Undersökning, C-640: 1-487.

Mörner N.-A., 1973 - Till stratigraphy in North America and northern Europe. Bulletin Geological Institute, University Uppsala, New Series, 5: 199-207.

Mörner N.-A., 1975 - Project B: Postglacial Earth Movements. In: Swedish Geodynamic Project. A summary of current research activities. National Report, IUGG XVI General Assembly, Grenoble 1975, p. 1-10.

Mörner N.-A., 1977a - Past and present uplift in Sweden: glacial isostasy, tectonism and bedrock influence. Geologiska Föreningen i Stockholm Förhandlingar, 99 (1): 48-54. https://doi.org/10.1080/11035897709454988

Mörner N.-A., 1977b. The Fennoscandian uplift: geological data and their geodynamic implication. Abstracts "Earth Rheology and Late Cenozoic Isostatic Movements" Symposium, Stockholm July 31 - August 3, 1977, p. 92-101.

Mörner N.-A., 1977c - Rörelser och instabilitet $i$ den svenska berggrunden: geo-arv, landhöjning, oregelbundenheter, senglacial tektonik/seismicitet, framtidsutsikter. KBS, Teknisk Rapport 18, p. 1-36.

Mörner N.-A., 1978 - Faulting, fracturing and seismic activity as a function of glacial isostasy. Geology, 6: 41-45. https://doi.org/10.1130/0091-7613(1978)6\%3C41: FFASAF\%3E2.0.CO;2

Mörner N.-A., 1979 - The Fennoscandian uplift and Late Cenozoic Geodynamics: Geological evidence. GeoJournal, 3 (3): 287-318.

https://doi.org/10.1007/BF00177634

Mörner N.-A., 1980 - The Fennoscandian uplift: geological data and their geodynamical implication. In: Mörner N.A. (Ed.), Earth rheology, isostasy and eustasy, John Wiley \& Sons, Chichester, p. 251-284.

Mörner N.-A., 1985 - Paleoseismicity and geodynamics in Sweden. Tectonophysics, 117: 139-153. https://doi.org/10.1016/0040-1951(85)90242-2

Mörner N.-A., 1990 - The Swedish failure in defining an acceptable bedrock repository for nuclear waste deposition. Geologiska Föreningen i Stockholm Förhandlingar, 112: 375-380.

https://doi.org/10.1080/11035899009452738

Mörner N.-A., 1991 - Intense earthquakes and seismotectonics as a function of glacial isostasy. Tectonophysics, 188: 407-410. https://doi.org/10.1016/0040-1951(91)90471-4

Mörner N.-A., 1993 - Methane dehydration tectonics. Bull. INQUA Neotectonics Commission 16: 71-72.

Mörner N.-A., 1999 - Sweden Excursion: sea level changes, uplift, paleoseismicity, climate, coastal dynamics. An INQUA-IGCP international excursion. Paleogeophysics \& Geodynamics, 81 p.

Mörner N-A., 2003 - Paleoseismicity of Sweden a novel paradigm. A contribution to INQUA from its Subcommission on Paleoseismology at $16^{\text {th }}$ International INQUA Congress in Reno, Nevada. Stockholm University, P\&G print, p.1-320.

Mörner N.-A., 2007 - The Fenris Wolf in the Nordic Asa creed in the light of palaeoseismics. In: Piccard L. \& Masse W.B. (Eds.), Myth in geology. Geological Society of London, Special Publications, 273: 117-119.

https://doi.org/10.1144/GSL.SP.2007.273.01.10
Mörner N.-A., 2009 - Late Holocene earthquake geology in Sweden. Geological Society of London, Special Publications, 316: 179-188. https://doi.org/10.1144/SP316.11

Mörner N.-A., 2010 - Seismotektoniska grottor $i$ Finland. Grottan, 2010 (4): 6-14.

Mörner N.-A., 2011 - Paleoseismology: the application of multiple parameters in four case studies in Sweden. Quaternary International, 242: 65-75.

https://doi.org/10.1016/j.quaint.2011.03.054

Mörner N.-A., 2013a - Drainage varves, seismites and tsunamites in the Swedish Varve Chronology. GFF, 135: 308-315.

https://doi.org/10.1080/11035897.2013.764546

Mörner N.-A., 2013b - Pattern in seismology and palaeoseismology, and their application to long-term hazard assessments - the Swedish case in view of nuclear waste management. Pattern Recognition in Physics, 1: 75-89.

https://doi.org/10.5194/prp-1-75-2013

Mörner N.-A., 2016a - Tsunamis in Sweden: Occurrence and characteristics. In: Mokhtari M. (Ed.), Tsunami. InTech, p. 115-133.

https://doi.org/10.5772/63956

Mörner N.-A., 2016b - Seismic hazard assessment: a challenge for science and geoethics. International Journal of Earthquake Engineering and Hazard Mitigation, 4 (2): 64-70.

Mörner N.-A., 2017a - Converting tsunami wave heights to earthquake magnitudes. Open Journal of Earthquake Research, 6: 89-97.

https://doi.org/10.4236/ojer.2017.62005

Mörner N.-A., 2017b - Methane hydrate in crystalline bedrock and explosive methane venting tectonics. Earth-Science Reviews, 169: 202-212.

https://doi.org/10.1016/j.earscirev.2017.05.003

Mörner N.-A., 2017c - Methane hydrate in crystalline bedrock and explosive methane venting tectonics. Supplementary data. Earth-Science Reviews, 169: 202212. https://doi.org/10.1016/j.earscirev.2017.05.003

Mörner N.-A., 2017d - Jordbävningar, Grundvattens rörelser och Geoetik. Slutanförande i Miljödomstolen rörande kärnavfallsförvaring i Forsmark. ResearchGate, Oktober 30.

https://www.researchgate.net/publication/320716450

Mörner N.-A., 2017e. Pukeberggrottan och dess närområde i ny belysning. Grottan, 2017 (1): 10-19.

Mörner N.-A., Tröften P.E., Sjöberg R., Grant D., Dawson S., Bronge C., Kvamsdal O. \& Sidén A., 2000 - Deglacial paleoseismicity in Sweden: the 9663 BP Iggesund event. Quaternary Science Reviews, 19: 1461-1468.

https://doi.org/10.1016/S0277-3791(00)00095-0

Mörner N.-A., Audemard F., Bronge C., Dawson S., Grant D., Kvamsdal O., Nikonov A., Sidén A., Sjöberg R., Strandh L., Sun G., Tröften P.E., Wigren H. \& Zykov D., 2003 - The Hudiksvall area: The Boda Cave and its surroundings. The $9663 v B P$ paleoseismic event. In: Mörner N.-A. (Ed.), Paleoseismicity of Sweden: a novel paradigm, A contribution to INQUA from its subcommission on Paleoseismology, p. 29-224. P\&G-print, Stockholm University.

Mörner N.-A. \& Dawson S., 2011 - Traces of tsunami events in off- and on-shore environments. Case studies in the Maldives, Scotland and Sweden. In: N.-A. Mörner, (Ed.), The tsunami threat - Research and technology, InTech, p. 371-388. https://doi.org/10.5772/13686

Mörner N.-A. \& Sun G., 2008. Paleoearthquake deformations recorded by magnetic variables. Earth and Planetary Science Letters, 267: 495-502. https://doi.org/10.1016/j.eps1.2007.12.002 
Mörner N-A., Sjöberg R. \& Audemard F., 2008 Paleoseismicity and Uplift of Sweden. 33 ${ }^{\text {rd }}$ International Geological Conference, The Nordic Countries 2008, Excursion Guide 11, 109 p.

Mörner N.-A. \& Sjöberg R., 2011 - Second International Conference on Granite Caves, Sweden, 2011. Excursion Guide. Sveriges Speleolog-Förbund, Svenska Grottor, 12: $1-28$.

Mörner N.-A. \& Tröften P.E., 1993 - Paleoseismotectonics in glaciated cratonal Sweden. Zeitschrift für Geomorphologie, 94:107-117.

Nikolaeva S.B., Nikonov A.A., Shvarev S.V. \& Rodkin M.V., 2018 - Detailed paleoseismological research on the flank of Lake Imandra depression (Kola region): new approaches and results. Russian Geology and Geophysics, 59: 697-708. https://doi.org/10.1016/j.rgg.2018.05.008

Nilsson E., 1968 - Södra Sveriges senkvartära historia. Geokronologi, issjöar och landhöjning. Kungl. Svenska Vetenskaps Akademins Handlingar, Series 4, 12 (1), 114 p.

von Post L., 1929. Kvartära bildningar. Sveriges Geologiska Undersökning, Aa 167: 39-96.

Rodkin M.V., Nikonov A.A. \& Shvarev S.V., 2012 Seismic impact estimation from data on deformations and displacements in rock massifs. Geodynamics \& Tectonophysics, 3: 203-237.

Shvarev S.V. \& Rodkin M.V., 2017 - Structural positions and settings of the paleoearth- quakes in area of the mount Vottovaara (Middle Karelia, eastern part of the Fennoscandian sheet). Problems in Engineering Seismology, 44 (2): 35-60.

Sjöberg R., 1981 - Tunnel-caves in Swedish Archaean rocks. Transactions of the British Cave Research Association, 8: 159-167.

Sjöberg R., 1982 - Tunnelgrottor $i$ södra Västerbotten, morfografiska och morfogenetiska studier. Gerum Reports A31, Department of Geography, Umeå University.

Sjöberg R., 1983a - Tunnelgrottor $i$ södra och mellersta Sverige, morfografiska studier. Gerum Reports C59, Department of Geography, Umeå University.

Sjöberg R., 1983b - Sammanfattning av grottinventering $i$ ångermanlandsdelen av Västernorrlands län 1980 1983. Grottan, 1983 (1): 8-19.

Sjöberg R., 1984 - Grottor Nolaskogs och $i$ Skuleskogen. Svenska Grottor, 6, $81 \mathrm{p}$.

Sjöberg R., 1985 - Tunnelgrottor $i$ Västernorrlands län, morfografiska och morfogenetiska studier. Gerum Reports C69, Department of Geography, Umeå University.

Sjöberg R., 1986a - A proposal of a classification system of granitic caves. Comunicacions 9, Congreso
Internacional de Espeleologia. Barcelona, Espana 1986, Part 2: 291-293.

Sjöberg R., 1986b - Tunnelgrottori Norden. Geomorfologiska studier. Gerum Naturgeografi, 3, Department of Geography, Umeå University.

Sjöberg R., 1986c - Caves indicating neotectonics in Sweden. Geografiska. Annaler 68A (4): 393-398.

Sjöberg R., 1987a - Caves as indicators of neotectonics in Sweden. Zeitschrift für Geomorphologie (Supplement), 63: $141-148$

Sjöberg R., 1987b - An inventory of caves in the county of Västernorrland N. Sweden. In: Gardiner V. (Ed.), International Geomorphology Part II, p. 1191-1198. London.

Sjöberg R., 1990 - Distribution of pseudokarst-caves in Sweden. Proceedings of the IV International Symposium on Pseudokarst. Podolanky v Beskydach. Praha, 92-97.

Sjöberg R., 1991 - Weathering studies on Pseudokarstcaves along the northern swedish coast. Zeitschrift für Geomorphologie, 35 (3): 305-320.

Sjöberg R., 1994a - Bedrock caves and fractured rock surfaces in Sweden. Occurrence and origin. Ph.D.thesis, Stockholm University, P\&G, 7: 1-112.

Sjöberg R., 1994b - Tunnel-caves in Sweden. Morphological and morphogenetical studies. Sveriges Speleolog-Förbund, Svenska Grottor, 8, 44 p.

Sjöberg R., 2008 - Många grottor på internationell geoexkursion. Grottan, 2008 (2): 34-37.

Sjöberg R., 2009 - Metangasutbrott bildade blockgrottor. Grottan, 2009 (3): 34-39.

SSF 2018. Sveriges Speleolog-Förbund, Grottdatabasen. http://basen.speleo.se/rel/login.php

Tell L., 1955 - Underjordens Vackra Värld, Stockholm.

Tell L., 1962 - Die Höhlentypen Schwedens. Arkiv för Svensk Grottforskning, 2, Norrköping.

Tell L., 1963 - Preliminär katalog över Grottor $i$ Sverige. Arkiv för svensk Grottforskning, 3, Norrköping.

Tell L., 1966 - Supplement nr. 1 till Grottor i Sverige. Arkiv för Svensk Grottforskning, 6, Norrköping.

Tell L., 1969 - Urbergsgrottor. Arkiv för Svensk Grottforskning, 9, Norrköping.

Tell L., 1970: Supplement nr. 2 till Grottor $i$ Sverige. Arkiv för Svensk Grottforskning, 10, Norrköping.

Tell L., 1974: Supplement nr. 3 till Grottor i Sverige. Arkiv för Svensk Grottforskning, 13, Norrköping.

Tröften P.E., 1997 - Neotectonics and paleoseismicity in southern Sweden with emphasis on sedimentological criteria. Ph.D. Thesis, Stockholm University, P\&G, 8: 1-124. 